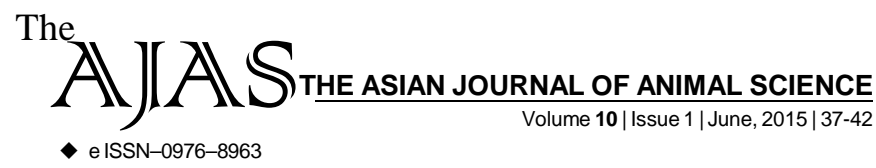

DOI : 10.15740/HAS/TAJAS/10.1/37-42 Visit us | www.researchjournal.co.in $\mathrm{S}$

RESEARCH ARTICLE.........

\title{
Histochemical studies on the angioarchitecture of coronary artery in goat (Capra hircus)
}

\author{
S. SATHAPATHY, S.K. JOSHI, S.P. KHANDATE, R.S. DALVI, R.Y. CHARJAN, U.P. MAINDE, S.B. \\ BANUBAKODE AND M.K. SINGH \\ BANUBAKODE AND M.K. SINGH
}

Author for Corresponding -

\section{S. SATHAPATHY}

Department of Veterinary

Anatomy and Histology, Nagpur

Veterinary College, Maharashtra

Animal and Fishery Sciences

University, NAGPUR (M.S.) INDIA

Email: srinivas.sathapathy@gmail.com

See end of the article for

Coopted authors'

\begin{abstract}
The present study was conducted on the coronary artery of 18 goats divided into three age groups viz., kid (up to 1 year), young (1-2 years) and adult ( 2 years and above) comprising of six animals in each group for recording the histchemical peculiarities. The histochemical study revealed that the PAS activity was limited to the tunica externa and intima of the coronary artery. Moderate PAS activity was recorded in the left coronary artery at the termination in all the age groups of goats, while at the origin of the right coronary artery very weak PAS activity was found. The deposition of lipids was found in all the tunics of the coronary artery. The amount of deposition of lipids in the tunica intima of left coronary artery was more than that deposited in the right one in all the age groups of goat and the deposition increased with the advancement of the age of the animals. The acid phosphatase activity was exhibited only in the endothelium and tunica externa of the coronary artery, whereas the alkaline phosphatase activity was noted in the endothelium, externa and perivascular connective tissues of the vessels. In adults, intense acid phosphatase activity was recorded in the tunica externa of left coronary artery with the endothelium showing very weak activity, while moderate activity was noted in the tunica externa of right coronary artery without any activity in the endothelium of this vessel in the adult animals. The present study shall be of value to clinicians for assessment of vascular configuration in health and diseases of coronary artery as well to study the haemodynamics in terms of lining endothelium and its modification for clotting mechanism.
\end{abstract}

KEY WORDS....... Histochemical, Angioarchitecture, Coronary, Artery, Goat

HOW TO CITE THIS ARTICLE - Sathapathy, S., Joshi, S.K., Khandate, S.P., Dalvi, R.S., Charjan, R.Y., Mainde, U.P., Banubakode, S.B. and Singh, M.K. (2015). Histochemical studies on the angioarchitecture of coronary artery in goat (Capra hircus). Asian J. Animal Sci., 10(1) : 37-42.

ARTICLE CHRONICLE - Received : 30.07.2014; Revised : 21.04.2015; Accepted : 08.05.2015 